UNITED STATES DEPARTMENT OF THE INTERIOR GEOLOGICAL SURVEY

\title{
PETROLEUM POTENTIAL OF WILDERNESS LANDS,
} UTAH

By Cornelius M. Molenaar, Charles A. Sandberg, and Richard B. Powers 


\section{Petroleum Potential of Wilderness Lands in \\ Utah}

By Cornelius M. Molenaar and Charles A. Sandberg

PETROLEUM POTENTIAL OF WILDERNESS LANDS IN THE WESTERN UNITED STATES

GEOLOGICAL SURVEY CIRCULAR $902-\mathrm{K}$

This chapter on the petroleum geology and resource potential of

Wilderness Lands in Utah is also provided as an accompanying pamphlet for Miscellaneous Investigations Series Map I-1545 


\section{CONTENTS}

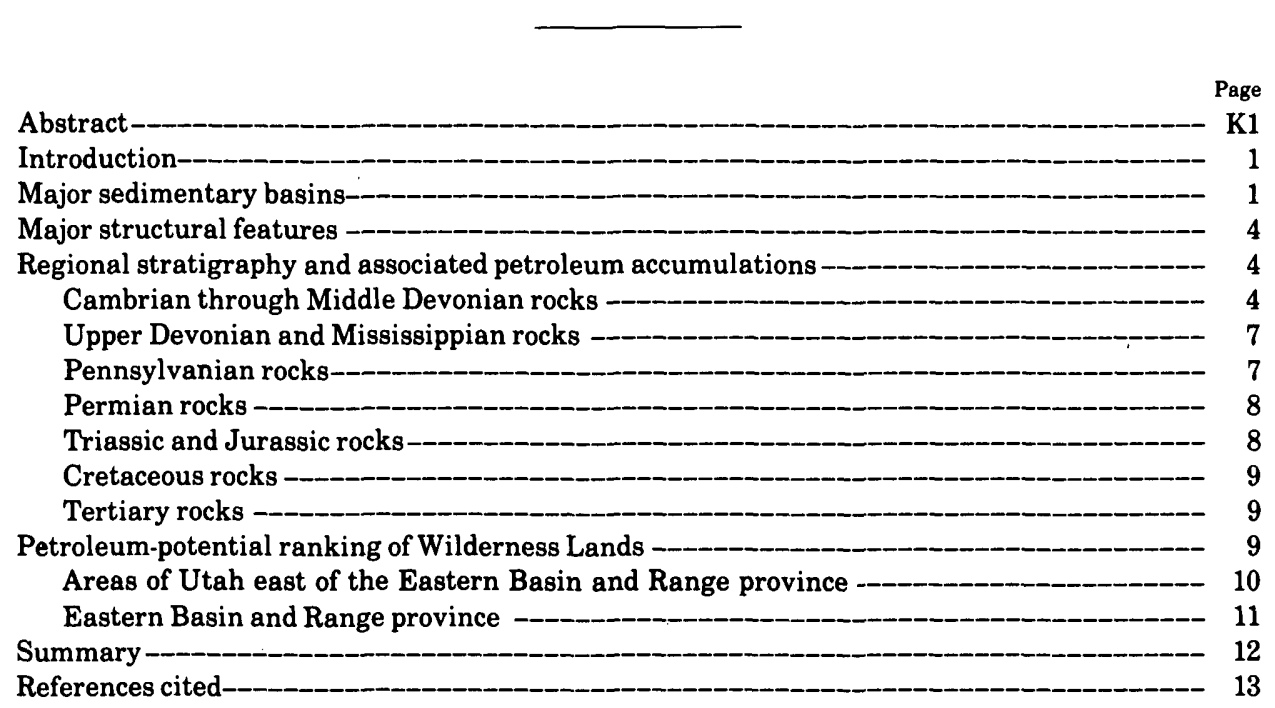

\section{ILLUSTRATIONS}

Figure 1. Map of Utah showing Wilderness Lands, present structural features, and medium and larger sized oil and gas fields

2. Map of Utah showing Wilderness Lands and tract clusters, USGS petroleum provinces, and medium and larger sized oil and gas fields -

3. Map of Utah showing Wilderness Lands, selected ancestral uplifts, leading edge of Sevier thrust system, distribu. tion of important Upper Devonian and Mississippian hydrocarbon source rocks, and an area in western Utah with favorable thermal history for hydrocarbon generation

\section{TABLE}




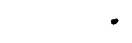




\title{
PETROLEUM POTENTIAL OF WILDERNESS LANDS IN THE WESTERN UNITED STATES
}

\section{Petroleum Potential of Wilderness Lands in Utah}

\author{
By Cornelius M. Molenaar and Charles A. Sandberg
}

\begin{abstract}
Utah contains parts of several sedimentary basins ranging in age from early Paleozoic to early Tertiary. Structural events that occurred during or after deposition have divided the State into separate basins or provinces having different hydrocarbon potentials. The provinces containing most of the larger oil and gas fields and also having the greatest petroleum potentials are the Paradox basin of southeastern Utah, the Uinta basin of northeastern Utah, and the thrust belt of north-central Utah. Wilderness Lands throughout the State are grouped for convenience into clusters having similar resource attributes. Petroleum potential of these clusters is qualitatively evaluated as zero, low, medium, or high with respect to the province in which they are located. These evaluations are based on (1) stratigraphic setting or exploration objectives, (2) structural setting, (3) petroleum source rocks and thermal history, and (4) results of previous exploration in the area. Most of the Wilderness Lands are classified as having low and medium potentials.
\end{abstract}

\section{INTRODUCTION}

Lands classified as Wilderness Lands are scattered throughout the State of Utah (fig. 1). These lands include BLM Further Planning or Study Areas and BLM Lands under Appeal, USFS Designated Wilderness, USFS Administratively Endorsed as Suitable, USFS Further Planning or Study Areas and NPS Administratively Endorsed as Suitable. The purpose of this report is to qualitatively assess the petroleum potential of these Wilderness Lands by relating the tracts to their overall stratigraphic and structural setting and comparing them with areas of known oil and gas fields of Utah.

Much of the State has been explored for oil and gas, including some areas now classified as Wilderness Lands. Many areas of the State, however, have been only lightly or never explored because of low potential or lack of exploration techniques necessary to resolve the subsurface geology. Large hydrocarbon accumulations have been discovered in several different basins or parts of basins. The three areas of significant production are
(1) the Paradox basin of southeastern Utah, (2) the Uinta Basin of northeastern Utah, and (3) the thrust belt of north-central Utah (figs. 1 and 2). In addition, a few small- and medium-size fields have been found outside of these three major producing areas.

The discussion of the geology is very brief and generalized and much of the discussion is based on Hintze (1973) or the many papers in Mallory (1972a). However, there are many reports, too numerous to list here, that cover the geology of different parts of Utah. A geological highway map by Hintze (1975) at a scale of 1:1,000,000 is useful in relating the Wilderness Lands to the local geology. Because of the impact of recent exploration in the thrust belt, which includes part of Utah, the thrust belt will be covered in more detail by R. B. Powers in chapter $\mathrm{N}$ in this circular.

\section{MAJOR SEDIMENTARY BASINS}

Utah has been the site of all or parts of several large sedimentary basins of diverse character and age throughout Phanerozoic (Cambrian and later) time. Many of the basins have subsequently been uplifted, deformed or disrupted, at least in part, by later tectonic events, primarily during latest Cretaceous and early Tertiary time and later during late Tertiary time, especially in the western third of the State (Eastern Basin and Range province). Some of the younger basins are superposed on parts of older basins. The major sedimentary basins that include parts of Utah are, in chronological order, (1) the Paleozoic Great Basin, a large shelf basin that traversed western Utah and bordered the North American cratonic shelf to the east, (2) the Pennsylvanian-Permian Paradox basin of southeastern Utah, (3) the Pennsylvanian-Permian Oquirrh basin of centralnorthwestern Utah, (4) the Western Interior seaway, a north-south trending Cretaceous basin that extended throughout the Western Interior of the 


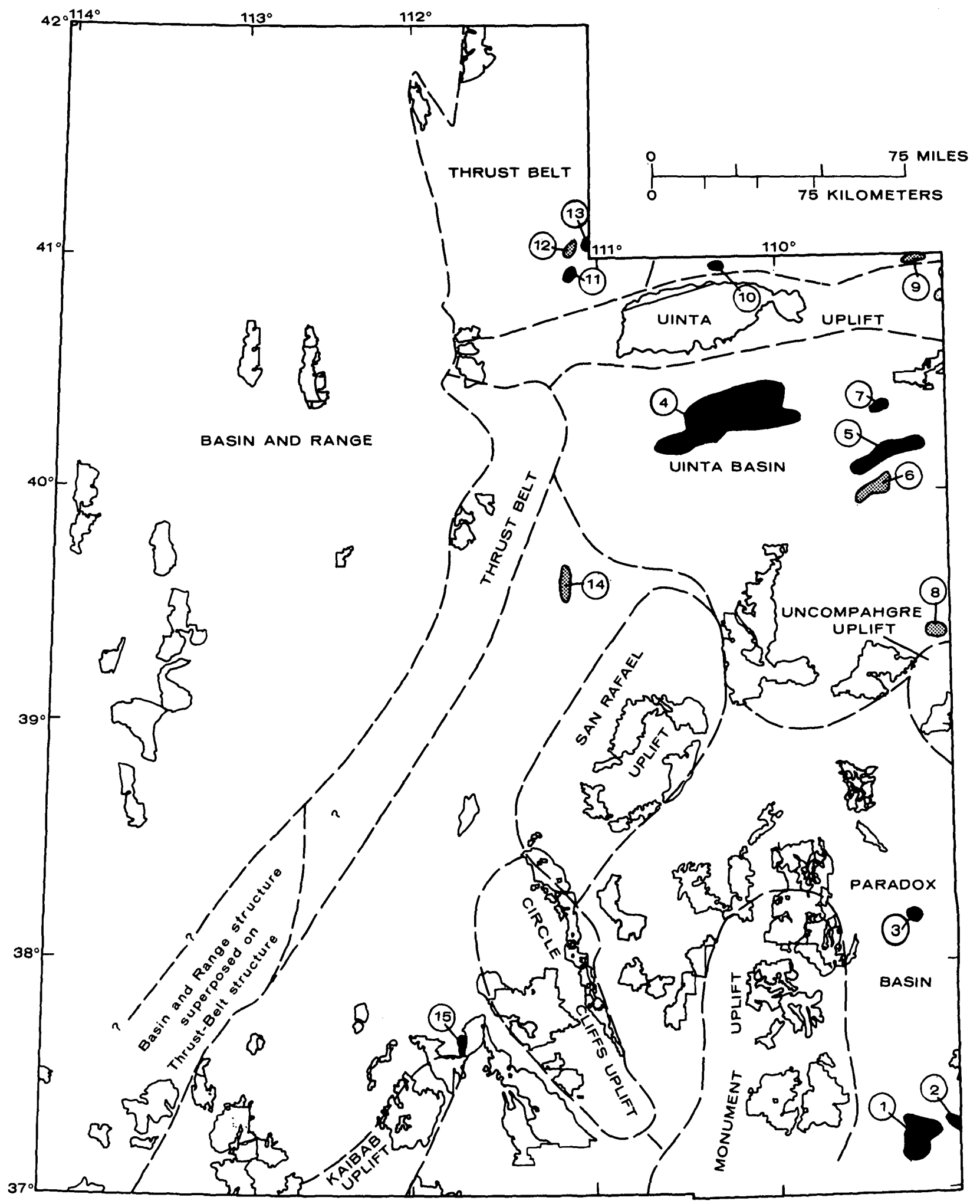

FIGURE 1.-Map of Utah showing Wilderness Lands (outlined), present structural features, and medium and larger sized oil (black pattern) and gas (gray pattern) fields, whose numbers are in circles. (See table 1 for names of fields and pertinent field data). 


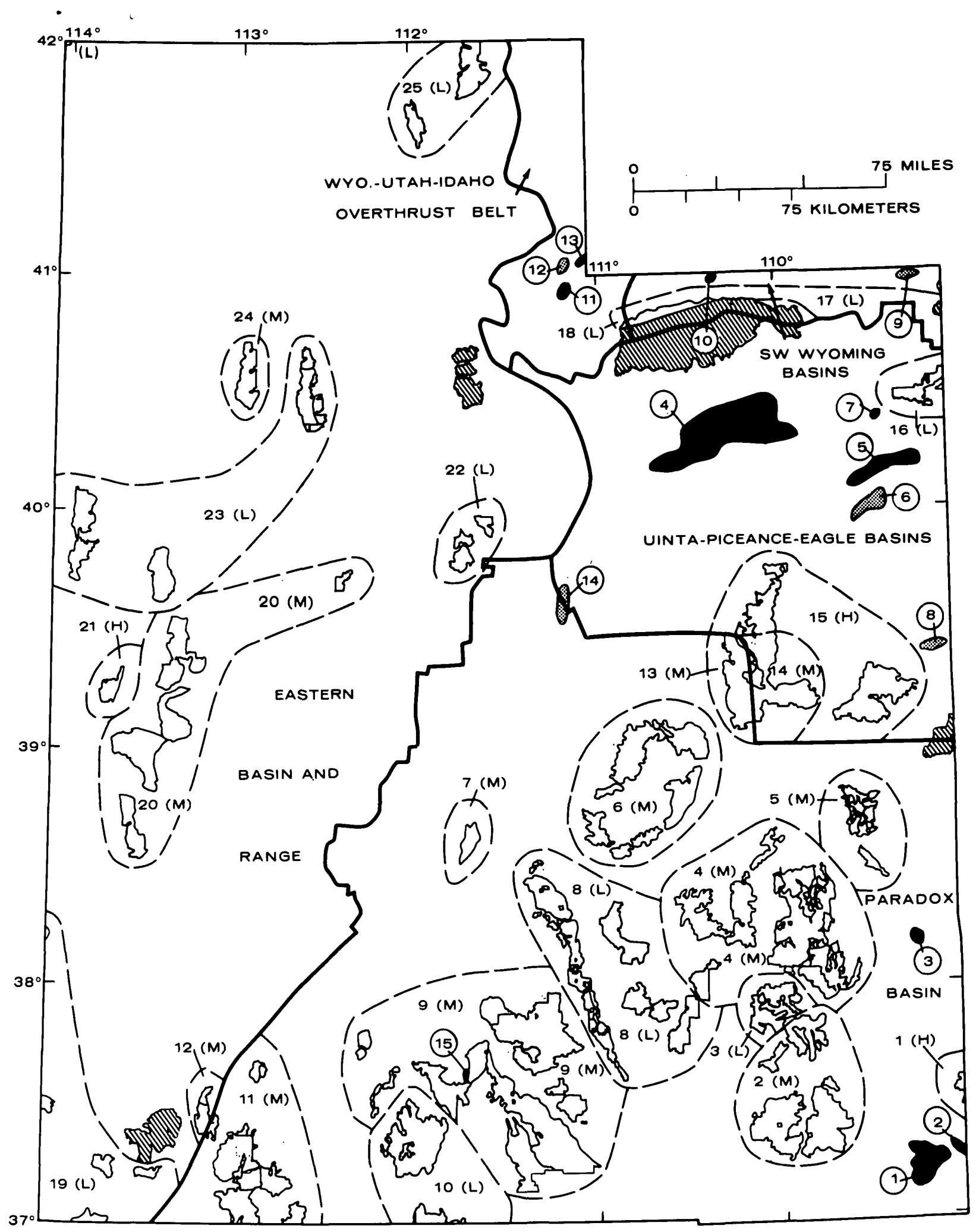

FIgURE 2.-Map of Utah showing Wilderness Lands (outlined) and numbered tract clusters (dashed lines and numbers), USGS petroleum provinces (heavy black lines), and medium and larger sized oil (black pattern) and gas (gray pattern) fields, whose numbers are in circles. (See table 1 for names of fields and pertinent field data). Petroleum potential of tract clusters is ranked zero (diagonal hatched), low $(\mathrm{L})$, medium $(\mathrm{M})$, and high $(\mathrm{H})$ with respect to the provinces in which they are located. 
United States and Canada and includes the eastern two-thirds of Utah, and (5) the Uinta Basin, an early Tertiary basin in northeastern Utah. In addition, the narrow belt of sedimentary rocks north of the Uinta Mountains is the southernmost part of the early Tertiary Green River basin of Wyoming. There are several other early Tertiary basins in Utah, but late Tertiary epeirogenic uplift of the Colorado Plateau, which includes areas in Utah south of the Uinta Mountains and east of the Wasatch Mountains, has resulted in dissection or removal by erosion of much of the Tertiary section in most Tertiary basins except the Uinta basin.

\section{MAJOR STRUCTURAL FEATURES}

Several major structural elements in Utah are recognized from surface structures. Generally from west to east, these are the Eastern Basin and Range province in western Utah, the thrust belt in central and northern Utah, the Kaibab uplift and Circle Cliffs uplift in south-central Utah, the San Rafael uplift in east-central Utah, the Uinta uplift in northern Utah, the Monument uplift in southeastern Utah, and the Uncompahgre uplift, which extends into central-eastern Utah from Colorado (fig. 1). The Eastern Basin and Range province is a series of late Tertiary to Quaternary horsts and grabens. The thrust belt is a Late Jurassic to earliest Tertiary compressional fold and thrust-fault belt that extended across Utah from the northern part to the southwest corner of the State. The later Basin and Range structure (essentially the area west of the Wasatch Mountain front) marks the present west boundary of the thrust-belt province in northern Utah. The areas of thrust faulting do continue farther west, but those areas are superposed by later Basin and Range structure, which is presently the dominant surface feature. In places, the boundary between the two structural provinces is arbitrary because of this overlap, and in southern Utah, the Basin and Range structure overlaps the entire thrust belt.

The uplifts east of the thrust belt or east of the Basin and Range in southern Utah are latest Cretaceous to early Tertiary in age. Many of these uplifts had earlier movements, or overlapped parts of earlier uplifts. The Basin and Range province probably contained older PennsylvanianPermian uplifts and certainly was involved in Late Iurassic to Cretaceous orogenic movements. Parts of the Kaibab, Circle Cliffs and San Rafael uplifts were part of the larger Piute platform, a Pennsylvanian feature (Mallory, 1972b). The Uncompahgre uplift was primarily active during the Pennsylvanian and Permian; its Laramide or later movement was relatively minor, at least in Utah. Figure 3 shows selected ancestral uplifts that are discussed.

\section{REGIONAL STRATIGRAPHY AND ASSOCIATED PETROLEUM ACCUMULATIONS}

For purposes of discussion of major stratigraphic units and their contained petroleum accumulations, the Phanerozoic sedimentary section is here divided into seven packages, each one having somewhat common characteristics relating to its depositional history or petroleum potential. In ascending order, the ages of the rocks comprising these packages are (1) Cambrian through Middle Devonian, (2) Upper Devonian and Mississippian, (3) Pennsylvanian, (4) Permian, (5) Triassic and Iurassic, (6) Cretaceous, and (7) Tertiary.

In the discussion of oil and gas fields associated with the various rock units, small-size fields are those with ultimate recoveries of less than 10 million barrels (MMB) of oil or 60 billion cubic feet (BCF) of gas, medium-size fields are those between 10 and $50 \mathrm{MMB}$ oil or 60 and $300 \mathrm{BCF}$ gas, large-size fields are those between 50 and 100 MMB oil or 300 and $600 \mathrm{BCF}$ gas, and giant-size fields are those larger than $100 \mathrm{MMB}$ oil and 3,000 BCF gas. Table 1 lists some pertinent data on the medium- and larger-size oil and gas fields of Utah.

\section{CAMBRIAN THROUGH MIDDLE DEVONIAN ROCKS}

Rocks included in the Cambrian through Middle Devonian package, although not necessarily an unbroken sequence, are present, at least in part, throughout Utah except in areas where they have been removed by erosion on ancestral uplifts, such as the Uncompahgre, Sevier, and parts of the Uinta uplifts (fig. 3), and on late Mesozoic and later uplifts. These rocks were deposited in mostly shallow-marine environments in a cratonic setting (thin shelf deposition on stable continental crust) in eastern Utah and in a shelf-basin setting where they aggregate in excess of 20,000 feet $(6,100 \mathrm{~m})$ in thickness in the area west of the Sevier thrust system (Hintze, 1973). This western area is part of the Great Basin. 


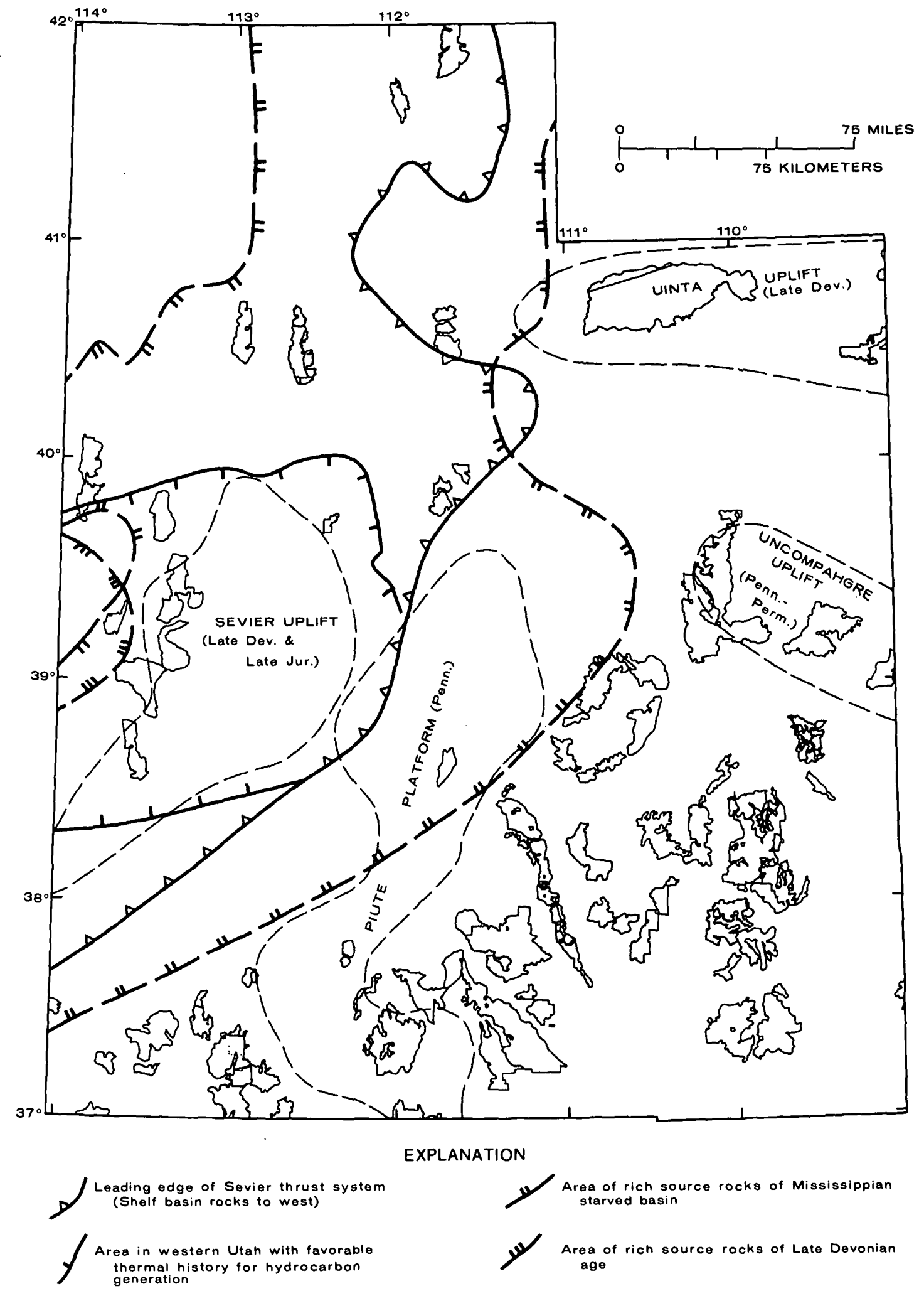

FIGURE 3.-Map of Utah showing Wilderness Lands (outlined), selected ancestral uplifts, leading edge of Sevier thrust system (Late Jurassic), distribution of important Upper Devonian and Mississippian hydrocarbon source rocks (from Sandberg and Gutschick, 1983; and Sandberg and Poole, 1975), and an area in western Utah that has a favorable thermal history for hydrocarbon generation ("cold spot" of Sandberg and Gutschick, 1977). 


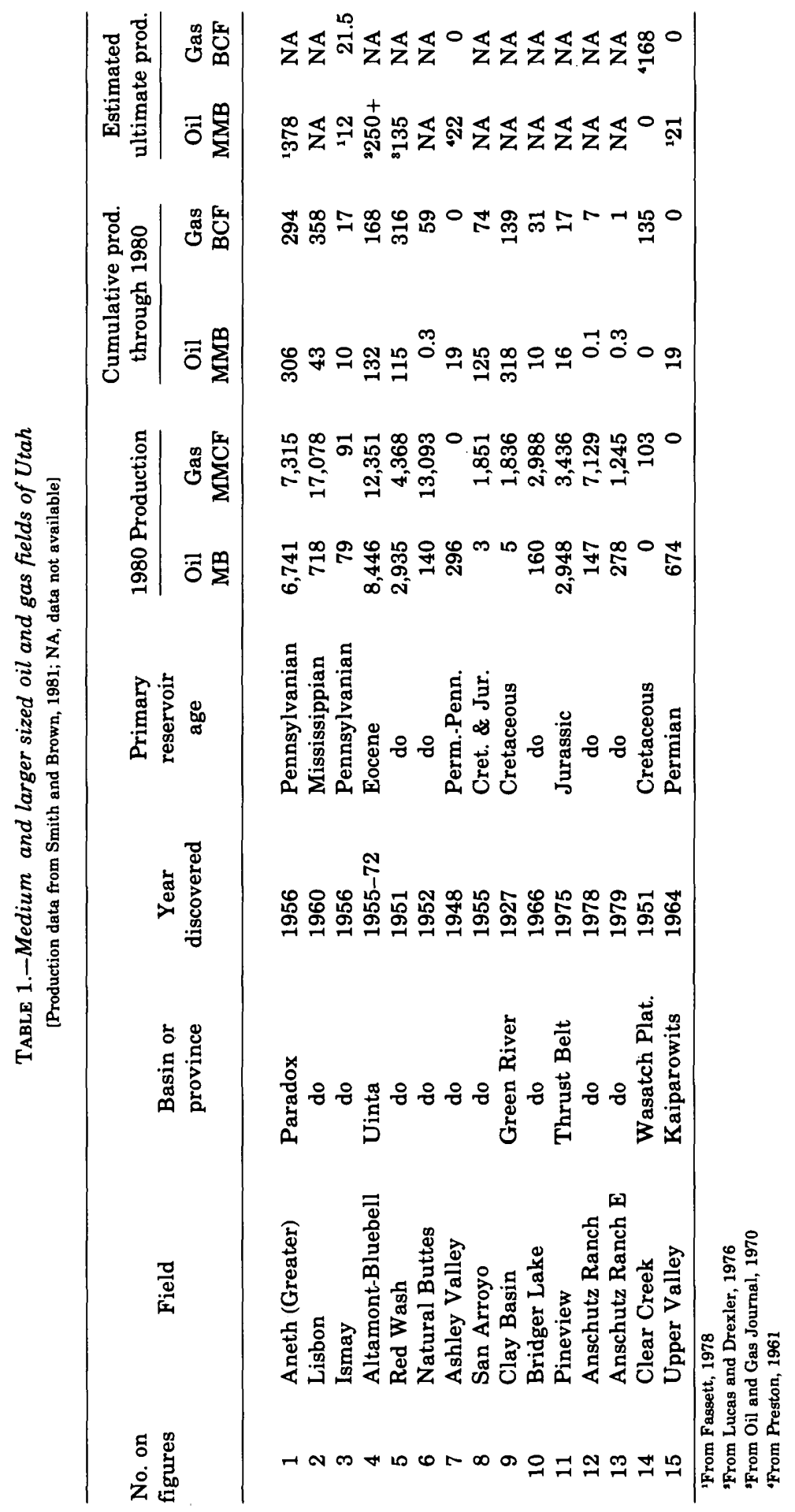


Rocks of this lower Paleozoic package consist generally of a basal sandstone and shale unit overlain predominantly by thick carbonate units (limestone and dolomite) with thinner interbeds of shale and sandstone. All the units of the cratonic sequence are thinner than equivalent units to the west and there are many disconformities or diastems within the section. For instance, Ordovician through Middle Devonian rocks are missing in eastern Utah. The shelf-basin sequence on the west contains much thicker units and a more complete section, although there are areas where uplifts such as the ancestral Sevier uplift (Sandberg and Poole, 1977) within the shelf basin resulted in removal of strata. In addition, because of the mobile nature of the shelf basin, there are more variations in depositional thicknesses.

There is no production in Utah from rocks of this package. However, in western Utah, recent drilling suggests that hydrocarbon source rocks are present in some of the Cambrian and possibly Lower Ordovician shales. In addition, oil shows in Cambrian dolomites have been reported from drill holes in that area.

\section{UPPER DEVONIAN AND MISSISSIPPIAN ROCKS}

The Antler orogeny in central Nevada profoundly affected depositional patterns of Upper Devonian and Mississippian rocks. Although great differences in their lithologic character and paleotectonic setting would require that rocks of these two systems should be treated separately, for ease of assessment of hydrocarbon potential, they are grouped herein. For some of the profound paleotectonic and source-rock differences between these systems, the reader is referred to Sandberg and Poole (1977), Gutschick, Sandberg, and Sando (1980), and Sandberg and others (1983). Deposition of these rocks in the Eastern Great Basin was complicated by intrabasinal uplifts (ancestral Sevier and Stansbury uplifts) shedding clastics into surrounding areas in part of Late Devonian time concurrent with foreland trough development that continued into Mississippian time (Gutschick and Sandberg, 1983). In the Eastern Great Basin, Upper Devonian rocks consist of thick sections of carbonate, shale, sandstone, and locally, conglomerate. Overlying Mississippian rocks consist of thin starved-basin shale and argillaceous limestone with some sandstone tongues extending into the basin from deltas in the Uinta uplift to the east and the Antler orogenic high- lands to the west (Sandberg and others, 1983). To the southeast, Devonian and Mississippian rocks grade landward into a more stable cratonic-shelf facies. There the Upper Devonian consists of a basal organic black shale (locally) and sandstone unit overlain by dolomite with interbedded shale, all aggregating only a few hundred feet in thickness. The Mississippian consists of widespread shelf limestone and dolomite ranging from a few hundred to more than a thousand feet thick.

The only petroleum production from Upper Devonian and Mississippian rocks in Utah is in the Paradox basin (fig. 1). Mississippian carbonate rocks are the primary producing formation at Lisbon field, a structurally trapped oil and gas accumulation of large size (Parker, 1981; Smith and Prather, 1981). Upper Devonian carbonate rocks directly beneath the Mississippian, and sandstones at the base of the Upper Devonian are minor producing reservoirs in this field. The source rocks for the hydrocarbons in this field are thought to be Pennsylvanian organic-rich shale interbeds in the Paradox salt section (Murphy and Claypool, oral commun.), which is in fault contact with the Mississippian and Devonian reservoirs on the northeast flank of the structure. Mississippian carbonate rocks also are the producing formation at four small oil or gas fields in the Utah part of the Paradox basin.

Mississippian carbonate rocks generally have good reservoir properties, but good petroleum source rocks are not common in the Upper Devonian and Mississippian cratonic sequence, except for lowermost Upper Devonian shales (Aneth Formation) that are present in the southern Paradox basin (Spencer, 1975). In addition, shale and argillaceous limestone units of Mississippian age in north-central Utah and the Great Basin to the west are probably good source rocks.

\section{PENNSYlVANIAN ROCKS}

Rocks of the Pennsylvanian System are present in much of Utah but were stripped off or never deposited over the Pennsylvanian-Permian Uncompahgre and Piute platform uplifts. In addition, they are absent on the late Mesozoic-early Tertiary uplifts. The thickest sections of these rocks are in the Oquirrh basin of central-northwest Utah, where $13,000 \mathrm{ft}(3,962 \mathrm{~m})$ has been reported (Hintze, 1973), and in the Paradox basin of southeastern Utah, where as much as $8,000 \mathrm{ft}(2,438 \mathrm{~m})$ 
has been penetrated by drill holes. Elsewhere, Pennsylvanian strata thin rapidly toward adjacent platforms or shelves.

Pennsylvanian rocks were deposited in a wide range of depositional environments ranging from nonmarine eolian and fluvial to locally deep-marine environments. However, most of these rocks were deposited in a shallow-marine environment and characteristically consist of alternating layers of limestone, shale, and sandstone. The cyclic nature of deposition is caused by eustatic sea-level changes common to the Pennsylvanian Period. Thick deposits of evaporites, primarily halite, (Paradox Formation of industry usage) are present in the Paradox basin, and a thick eolian sandstone unit (Weber Formation) is present in northeastern Utah.

The major production in the Paradox basin comes from Pennsylvanian rocks. One giant-size field (Aneth), one medium-size field (Ismay), and many small-size fields produce from Middle Pennsylvanian (Desmoinesian) carbonate mounds along the southern flank of the basin (Peterson, 1966) (fig. 1 and table 1). The location of the porous mound development is stratigraphically controlled, but low-relief structures within the field area controls the oil-water contact. This type of stratigraphic trap is very difficult to identify or delineate by methods other than drilling. Interbedded or laterally adjacent organic-rich dolomitic shales are the source rocks for hydrocarbons in the southern Paradox basin.

In addition to the many fields in the southern Paradox basin, a few small one-well fields have produced oil from fractured siltstone and shale interbeds within the Paradox salt section in the northern Paradox basin.

Elsewhere, the only significant production from Pennsylvanian (and overlying Permian) rocks is at Ashley Valley field, a medium-size structurally trapped oil accumulation on the northeast flank of the Uinta Basin (fig. 1). The production comes from an eolian sandstone of Pennsylvanian-Permian age (Weber Sandstone).

\section{PERMIAN ROCKS}

Rocks of Permian age are present in most of Utah except on the Uncompahgre uplift, where they were never deposited, and on the late Mesozoic-Tertiary uplifts, where they have been removed by erosion. Like the Pennsylvanian, the thickest sections of Permian rocks are in the
Oquirrh and Paradox basins. Permian rocks conformably overlie Pennsylvanian rocks in basinal areas but unconformably overlie Pennsylvanian to Mississippian rocks on the Piute platform of central Utah.

Permian rocks consist of nonmarine and marginal-marine red beds and eolian sandstone on the east that grade to shallow-marine sandstones and limestones to the west. Like the Pennsylvanian sequence, deposition of marine rocks of the Permian is cyclic, consisting of alternating layers of limestone, sandstone, and shale. Rich hydrocarbon source rocks are present in northern Utah and were probably the origin of the oil occurring in several oil fields in northern Utah and Wyoming. For details of these source rocks and other Permian rocks of northern Utah, refer to Maughan (1979).

Two medium-size oil fields produce from Permian reservoirs; the previously mentioned Ashley Valley field in northeastern Utah, and the Upper Valley field in south-central Utah (fig. 1). The major, if not all, production at Ashley Valley probably is from the Permian part of the thick sandstone (Weber) reservoir. The Upper Valley field produces primarily from carbonate reservoirs in the Lower Permian Kaibab Limestone (Campbell, 1969). The trap is a south-southeast plunging anticline in which a hydrodynamic gradient of the formation water has caused an inclined oil -water contact (Sharp, 1978).

Permian sandstones and carbonate rocks also are secondary reservoirs in some of the fields in the thrust belt of northern Utah. In addition, large heavy-oil (tar) deposits occur at or near the surface in the Permian White Rim Sandstone in central-southeastern Utah. This accumulation occurs near the eastern pinch-out of the sandstone unit, and is an exhumed super-giant-size oil field.

\section{TRIASSIC AND JURASSIC ROCKS}

Triassic and Jurassic rocks are at or near the surface over much of the Paradox basin of southeastern Utah and are present in the deeper subsurface in the Uinta basin, the Wasatch Mountains and Plateau, and the thrust belt. They are missing largely by erosion and parts of the sequence were never deposited over most of the Great Basin part of Utah.

During deposition of the Triassic through Middle Jurassic part, which contains several colorful 
red-bed units, the seaway was to the west, northwest, and north. On the west and northwest, the sequence consists of three shallow-marine sandstone, shale, and limestone units separated by nonmarine fluvial or eolian deposits. To the east, all the units become thinner and the marine units pinch out.

Latest Jurassic rocks, which consist of fluvial sandstone and variegated shale (Morrison Formation), were derived from an orogenic belt in western Utah and farther south. These rocks were deposited in and beyond eastern Utah, which was part of the developing Western Interior geosyncline.

Because of the lack of petroleum source rocks in much of the section and because much of the section is at or near the surface in southeastern Utah, most of the Triassic and Jurassic rocks in southeastern Utah have little hydrocarbon potential. However, parts of the Lower Triassic limestones to the west are petroliferous and several small oil and gas fields produce from reservoirs in or near these limestones. Small oil and gas fields also are present in Jurassic sandstone reservoirs in faulted structural traps in the southeastern Uinta basin and northern Paradox basin.

In addition, large or giant oil and gas fields occur in the thrust belt of north-central Utah, where Jurassic sandstone reservoirs are in thrustfault contact with Cretaceous source rocks. The thrust-belt area is discussed by R. B. Powers in chapter $\mathrm{N}$ in this circular.

\section{CRETACEOUS ROCKS}

As much as $14,000 \mathrm{ft}(4,267 \mathrm{~m})$ of Cretaceous rocks were deposited in the Utah part of the Western Interior seaway. Most of these rocks have been eroded in Tertiary time and the more complete sections are preserved only in the Tertiary basins such as the Uinta basin, the Green River basin (a small part of which is in Utah on the north side of the Uinta Mountains), the Kaiparowits basin, and other areas such as under the Wasatch Plateau and in synclinal areas in the thrust belt. Cretaceous strata consist of thick sections of marine shale and siltstone that intertongue to the west with eastward-prograding wedges of thinner shallow-marine sandstone units and thicker nonmarine units of sandstone, shale, minor conglomerate, and coal. Organic-rich shale is present in parts of the thick marine shale section.
These shales are the probable source rocks for oil at the Bridger Lake field and gas at the Clay Basin field north of the Uinta Mountains and for the hydrocarbons in some of the Jurassic reservoirs in the thrust belt. In addition, one mediumsize gas field (San Arroyo, fig. 1) and several small oil and gas fields that produce from Jurassic and Lower Cretaceous sandstone reservoirs in the southeastern part of the Uinta basin were probably charged by Cretaceous source rocks. On the Wasatch Plateau of central Utah, carbonaceous shales and coals were probably the source rocks for the gas in the Clear Creek field, a medium-size accumulation in a structural trap.

\section{TERTIARY ROCKS}

Beginning in latest Cretaceous time and continuing into the lower Tertiary, Laramide structural movements developed separate internal drainage basins flanked by uplifts. The most prominent of these Tertiary basins in Utah is the Uinta basin in northeastern Utah. As much as $15,000 \mathrm{ft}(4570 \mathrm{~m})$ of Paleocene and Eocene shale, limestone, sandstone, and conglomerate were deposited in this intermontane basin. Much of this deposition, especially in the basin center, occurred in a lacustrine environment in which large amounts of organic matter were incorporated in the muds and marls. These organic-rich sediments, which intertongue with or are overlain by sand layers, have subsequently been buried deeply enough in the deeper parts of the basin to thermally generate hydrocarbons (Lucas and Drexler, 1976). As a result, two giant-size oil fields (Altamont-Bluebell and Red Wash) and one medium-size gas field (Natural Buttes) as well as many small gas or oil fields produce from early Tertiary sandstone reservoirs in stratigraphic traps in the deeper parts of the Uinta basin.

\section{PETROLEUM-POTENTIAL RANKING OF WILDERNESS LANDS}

The petroleum potential of the Wilderness Lands of Utah, most of which are in southeastern and southern Utah, were qualitatively ranked in respect to the petroleum province in which they are located (fig. 2). The petroleum provinces were 
used by the USGS for convenience in making resource appraisals of the entire United States (Dolton and others, 1981). Because of differences in age and overlapping of geologic basins, the province boundaries may or may not coincide with present geologic basin outlines. Utah includes parts of five provinces, which are (1) the Eastern Basin and Range, (2) the Paradox Basin (expanded), (3) the Uinta-Piceance - Eagle Basins, (4) the Wyoming-Utah-Idaho Overthrust belt, and (5) the Southwestern Wyoming Basins province.

The rankings of the Wilderness Lands range from zero through low, medium, and high potential. Zero potential areas are those in which basement or nonprospective rocks are at or near the surface. However, consideration is given to areas in which nonprospective rocks may be thrust over prospective rocks, such as along the north flank of the Uinta Mountains. Higher potential areas are those areas near oil and gas fields or areas having attributes that make them more favorable for petroleum than other areas of the particular province. A map of Utah has been prepared at a scale of 1:1,000,000 which shows the petroleum potential of Utah's Wilderness Lands (Miscellaneous Investigations Series Map I-1545, in press).

The factors by which the various lands are ranked include (1) stratigraphic setting or exploration objectives, (2) structural setting, (3) petroleum source rocks and thermal history, and(4) results of previous exploration in the area. Many Wilderness Lands have been explored for petroleum during the past 30 years, and some areas have been tested by drilling. A dry hole, however, doesn't necessarily condemn the entire tract or group of tracts and, indeed, some wells did not test deeper objectives. For convenience in describing the factors that went into assessing the various Wilderness Lands, the tracts are grouped into clusters of tracts in which the geologic attributes are similar. Twenty-five clusters of 'various sizes covering the five petroleum provinces are differentiated in figure 2.

\section{AREAS OF UTAH EAST OF THE EASTERN BASIN AND RANGE PROVINCE}

The area east of the Eastern Basin and Range province has been tested by drilling to a much greater extent than areas to the west, and the petroleum geology is better known. In addition, several oil and (or) gas fields are scattered through- out the area. These fields and the many dry drill holes provide much data with which to compare or rank the petroleum potential of the Wilderness Lands. The evaluation and the geologic attributes that affected the ranking of these clusters are as follows:

Cluster 1.-High potential. This area is not far from oil and gas fields producing from Pennsylvanian carbonate-mound reservoirs. It has the potential for a small field, although there are many dry holes surrounding the area.

Cluster 2.-Medium potential. This area is on the Monument uplift and many dry holes have been drilled throughout the area. Isolated Pennsylvanian carbonate-mound reservoirs may be present.

Cluster 3.-Low potential. This area is on the north plunge of the Monument uplift. Deep canyons dissect the area and Pennsylvanian strata are exposed at the north end.

Cluster 4.--Medium potential. This area includes or is adjacent to a huge heavy-oil (tar) deposit in the Permian White Rim Sandstone. Several dry Mississippian tests have been drilled on or adjacent to this cluster. The area is deeply dissected by the Colorado and Green Rivers and seismic resolution of subsurface structure is difficult. Mississippian prospects may still exist. In addition, Pennsylvanian stratigraphic traps are a possibility.

Cluster 5.-Medium potential. Differential salt flowage has occurred in this area and seismic resolution of presalt structure is difficult. Mississippian structures may be present in the area.

Cluster 6.-Medium potential. This area is on the San Rafael uplift-mostly on the flanks. Permian rocks are exposed on the crest of the uplift and heavy oil is present in some sandstone outcrops. The objectives in this area would be older rocks, most likely Mississippian carbonate rocks. Several dry holes are scattered throughout this area.

Cluster 7.-Medium potential. This area is covered by Tertiary volcanic rocks, thereby masking the structure of prospective Mississippian, Permian, Triassic, and Cretaceous rocks, all of which are in a favorable facies belt.

Cluster 8.-Low potential. This area falls along the Circle Cliffs monocline on the northeast side of the Circle Cliffs uplift and in the Henry basin, a structurally low area to the northeast. Much of 
the Wilderness Land in the Henry basin includes the Henry Mountains, which are Tertiary laccolithic intrusive rocks-a poor place to explore for petroleum.

Cluster 9.-Medium potential. This large area surrounds the Upper Valley field, a 21-MMB oil field that produces from Permian carbonate reservoirs. Oil shows were reported from other Permian formations in this field and a small amount of oil was produced from Mississippian carbonate rocks. Many dry holes have been drilled throughout the area, but possibilities still exist for oil accumulations in Permian or Mississippian reservoirs.

Cluster 10.-Low potential. This area lies mostly on the north plunge of the Kaibab uplift. This is a sparsely explored area, but several dry holes have been drilled. The Permian carbonate rocks that produce oil at Upper Valley field to the northeast are exposed at the surface of the uplift. Mississippian rocks would be the primary objective in this area.

Cluster 11.-Medium potential. This area includes Cedar Breaks National Monument, Zion National Park, and areas to the south and southeast. The Virgin oil field, a very small, shallowdepth subcommercial oil field that produced or is producing from a Lower Triassic sandy limestone reservoir, is located a few miles southwest of Zion Park. Oil shows were reported from Permian, Pennsylvanian, and Mississippian rocks penetrated by deeper tests (Driscoll, 1978). The Triassic and Jurassic strata at the surface in this cluster are very low dipping.

Cluster 12.-Medium potential. This small cluster borders the Hurricane fault zone and is on the upthrown block. A noncommercial field (Anderson Iunction field) produced a small amount of oil from a Pennsylvanian carbonate reservoir on this block a few miles south of the cluster. Fault-bounded structures may provide traps for oil in Mississippian through Permian reservoirs.

Cluster 13.-Medium potential. This area is on the south flank of the Uinta basin, which overlaps with the northern extent of the Paradox basin. In addition, the southwest-bounding fault of the Pennsylvanian-Permian Uncompahgre uplift cuts across the area. A few dry holes have been drilled on or adjacent to the cluster. Rugged topography of the Book Cliffs makes seismic definition of deep structure difficult.

Cluster 14.-Medium potential. Attributes of this cluster are the same as cluster 13. The two clusters are separated because they are in two different petroleum provinces. Cluster 14 is probably all, or mostly, on the Uncompahgre block, although there are no deep tests to verify this.

Cluster 15.-High potential. This area is on the south and southeast flank of the Uinta basin and is adjacent to and includes several small gas fields. The medium-size San Arroyo gas field lies to the northeast of the southeastern tract. Almost all these fields produce from small structural traps in basal Cretaceous and Jurassic sandstone reservoirs. One small oil field (Peters Point) located west of the northern tract produces a small amount of oil from a Tertiary reservoir.

Cluster 16.-Low potential. This area encompasses the western end of Dinosaur National Monument, which structurally is the steep-flanked Split Mountain anticline. Erosion by the Green River has exposed Mississippian and locally Cambrian rocks on the crest of the structure. The area has very low potential for hydrocarbons.

Cluster 17.-Low potential. This area lies along the north flank of the Uinta Mountains. Rocks at the surface are Precambrian in age, but because the fault that bounds the Uinta uplift dips to the south at an unknown angle, prospective Cretaceous rocks may be encountered at depth (Gries, 1983).

Cluster 18.-Low potential. Attributes of this cluster are the same as cluster 17 . The two clusters are separated because they are in two different petroleum provinces. This cluster falls within the southernmost edge of the Wyoming-UtahIdaho Overthrust Belt province.

\section{EASTERN BASIN AND RANGE PROVINCE}

The resource evaluation of frontier petroleum provinces, such as the Eastern Basin and Range province, presents problems quite distinct from those of the other four Utah provinces, which are in various stages of economic development. In developing provinces such as the Paradox basin, producing oil and gas fields provide analogs for predicting where and how similar accumulations might be found under matching sedimentary and structural conditions. In the Eastern Basin and Range province, however, subsurface control is so sparse that analogs are unavailable. Moreover, the geology is so complex, as described by C. A. Sandberg in chapter $\mathrm{L}$ of this circular that treats 
the part of this province lying in eastern Nevada, that reservoir rocks and traps can be presumed to be broadly distributed. Faults and fractures that might have leaked hydrocarbons to the surface as a result of Basin and Range block faulting are presumed to have been at least partly sealed before the cycle of generation thought to be presently in progress. Consequently, the prime parameters for resource evaluation are the presence of source rocks and their degree of maturation. Because source rocks in this province are of Paleozoic age, one method of determining their maturation is by examination of a unique group of microfossils called conodonts. Conodonts provide virtual geothermometers that readily tell by their temperature-induced color changes or conodont color-alteration index (CAI) values the maximum temperature to which containing rocks have been subiected. The CAI scale was developed by Epstein, Epstein, and Harris (1977). The utility of conodonts to petroleum exploration in this province and adjacent areas has been described by Sandberg and Poole (1977), Sandberg and Clark (1979), Sandberg (1980), and Sweet and others (1981). Papers by Sandberg and Poole (1975), Sandberg and Gutschick (1977, 1979), Sandberg, Grogan, and Clisham (1979), Sandberg, Poole, and Gutschick (1980), Sandberg and Gutschick (1980a, 1980b), and Harris and others (1980) provide CAI values and source-rock evaluations that were used in making the following resource evaluations.

Cluster 19.-Low potential. Tracts in this cluster lie either east of the Sevier thrust system (fig. 3), where Mississippian source rocks are thin or absent, or within the ancestral Sevier uplift, where source rocks were eroded. A low potential exists because of possible long-distance eastward petroleum migration that also may be responsible for the nearby Virgin oil field.

Cluster 20.-Medium potential. Tracts in this cluster have mainly Cambrian and. Lower Ordovician rocks at the surface because they lie mostly within the ancestral Sevier uplift (fig. 3), from which younger rocks were eroded. Some source rocks are present in this sequence, as indicated by exploratory wells just to the west in the Confusion Range. Moreover, one or more complete sequences of Paleozoic and (or) Mesozoic rocks might be expected in lower thrust plates at depth. As indicated by a deep exploratory test that was drilled within this cluster, near Delta, Utah (Mitchell, 1979), thermal maturation of hydrocar- bons would be optimum for oil and gas generation.

Cluster 21.-High potential. This single-tract cluster is located on Conger Mountain on a synclinal axis, but anticlinal structures could be expected at depth in lower thrust plates. Because this tract lies within the "cold spot" of Sandberg and Gutschick (1977) and within areas of rich source rocks of the Devonian Pilot Shale and Mississippian Chainman Shale (Sandberg, 1975; Sandberg and Poole, 1975; Sandberg, Poole, and Gutschick, 1980) and of the Mississippian Deseret starved basin (Sandberg and Gutschick, 1980a, $1980 \mathrm{~b})$, it has the greatest potential of any tract in the province. Oil is present in a spring just south of the tract and live oil is found in fossil cephalopods just east of the tract.

Cluster 22.-Low potential. Tracts of this cluster lie in the vicinity of Mount Nebo in the Wasatch Mountains. Conodont CAI values in the vicinity indicate that hydrocarbons are at the high range of maturity or are overmatured.

Cluster 23.-Low potential. Tracts in this cluster are situated in the Deep Creek and Fish Creek Ranges and Stansbury Mountains. Conodont CAI values of 3 to 6 indicate that hydrocarbons range from highly mature to overmatured.

Cluster 24.-Medium potential. This singletract cluster occupies the Cedar Mountains, which are formed mainly by Pennsylvanian and Permian rocks. The one conodont value reported from this area by Harris and others (1980) has a CAI value of only 1 , which would indicate very low thermal maturation of hydrocarbons. This value may be anomalously low, however, and optimum maturation could be expected at other localities in the tract and at depth.

Cluster 25.-Low potential. The eastern tract of this cluster occupies a major syncline along the crest of the Bear River Range. The western tract occupies Wellsville Mountain, the western prong of the Wasatch Mountains. The average conodont CAI values are 3.5 , a number which indicates that hydrocarbons are within the gas-generation window but at the upper end of the oil-generation window.

\section{SUMMARY}

Of the 4,482,727 acres involved in this study for the assessment of the petroleum potential of the Wilderness Lands in Utah, the potential acreage can be summarized as follows: high potential, 
$-1,140$

208.9 thousand acres; medium potential, 2,638.3 thousand acres; low potential, 1,010.4 thousand acres; and zero potential, 625.2 thousand acres. The petroleum potential by acreage of all Wilderness Land categories in the Western United States is shown in this circular by B. M. Miller in table 1 , chapter $P$.

\section{REFERENCES CITED}

Campbell, J. A., 1969, The Upper Valley oil field, Garfield County, Utah, in Four Corners Geological Society Guidebook: 5th Field Conference Geology and natural history of the Grand Canyon region, p. 195-200.

Dolton, G. L., Carlson, K. H., Charpentier, R. R., Coury, A. B., Crovelli, R.A., Frezon, S. E., Khan, A. S., Lister, J. H., McMullen, R. H., Pike, R.S., Powers, R. B., Scott, E. W., and Varnes, K. L., 1981, Estimates of undiscovered recoverable conventional resources of oil and gas in the United States: U.S. Geological Survey Circular 860, 87 p.

Driscoll, P. L., 1978, Virgin, in Oil and gas fields of the Four Corners area: Four Corners Geological Society, v. 2, p. $712-715$

Epstein, A. G., Epstein, J. B., and Harris, L. D., 1977, Conodont color alteration-an index to organic metamorphism: U.S. Geological Survey Professional Paper 995, 27 p.

Fassett, J. E., ed., 1978, Oil and gas fields of the Four Corners area: Four Corners Geological Society, v. 2, p. 369-727.

Gries, Robbie, 1983, Oil and gas prospecting beneath Precambrian of foreland thrust plates in Rocky Mountains: American Association of Petroleum Geologists Bulletin, v. 63, no. 1, p. 1-28.

Gutschick, R. C., and Sandberg, C. A., 1983, Mississippian continental margins of the conterminous United States, in The shelfbreak; critical interface on continental margins: Society of Economic Paleontologists and Mineralogists, Special Publication 33, p. 79-96.

Gutschick, R. C., Sandberg, C. A., and Sando, W. J., 1980, Mississippian shelf margin and carbonate platform from Montana to Nevada, in Fouch, T. D., and Magathan, E. R., eds., Paleozoic paleogeography of the west-central United States: Society of Economic Paleontologists and Mineralogists, Rocky Mountain Section, Rocky Mountain Paleography Symposium 1, p. 111-128.

Harris, A. G., Wardlaw, B. R., Rust, C. C., and Merrill, G. K., 1980, Maps for assessing thermal maturity (conodont color alteration index maps) in Ordovician through Triassic rocks in Nevada and Utah and adjacent parts of Idaho and California: U.S. Geological Survey Miscellaneous Investigations Series, Map I-1249, 2 sheets.

Hintze, L. F., 1973, Geologic history of Utah: Brigham Young University Geology Studies, v. 20, pt. 3, 181 p.

1975, Geological highway map of Utah: Brigham Young University, Department of Geology, scale 1:1,000,000.

Lucas, P. T., and Drexler, J. M., 1976, Altamont-Bluebell-a major, naturally fractured stratigraphic trap, Uinta Basin, Utah, in Braunstein, Jules, ed., North American Oil and Gas Fields: American Association of Petroleum Geologists Memoir 24, p. 121-135.
Mallory, W. W., ed., 1972a, Geologic atlas of the Rocky Mountain region: Rocky Mountain Association of Geologists, 331 p.

1972b, Regional synthesis of the Pennsylvanian System, in Geologic atlas of the Rocky Mountain region: Rocky Mountain Association of Geologists, Denver, Colorado, p. 111-142.

Maughan, E. K., 1979, Petroleum source rock evaluation of the Permian Park City Group in the northeastern Great Basin, Utah, Nevada, and Idaho, in Newman, G. W., and Goode, H. D., eds., Basin and Range Symposium: Rocky Mountain Association of Geologists and Utah Geological Association, p. 523-530.

Mitchell, G. C., 1979, Stratigraphy and regional implications of the Argonaut Energy No. 1 Federal, Millard County, Utah, in Newman, G. W., and Goode, H. D., eds., Basin and Range Symposium: Rocky Mountain Association of Geologists and Utah Geological Association, p. 503-514.

Oil and Gas Journal, 1970, Where are the reserves around the United States? v. 68, no. 4, p. 139.

Parker, J. M., 1981, Lisbon field area, San Juan County, Utah, in Rocky Mountain Association of Geologists Guidebook, 1981 Field Conference, Geology of the Paradox basin, p. 89-100.

Peterson, J. A., 1966, Stratigraphic vs. structural controls on carbonate mound hydrocarbon accumulation, Aneth area, Paradox Basin: American Association of Petroleum Geologists Bulletin, v. 50, no. 10, p. 2068-2081.

Preston, Don, ed., 1961, A Symposium of the oil and gas fields of Utah: Intermountain Association of Petroleum Geologists, p. not numbered.

Sandberg, C. A., 1975, Petroleum geology of Paleozoic rocks of Cordilleran miogeosyncline: U.S. Geological Survey OpenFile Report 75-96, 7 p., 6 figs.

1980 , Use of Devonian conodonts in petroleum exploration, Western United States (abs.): American Association of Petroleum Geologists Bulletin, v. 64, no. 5, p. 780.

Sandberg, C. A., and Clark, D. L., eds., 1979, Conodont biostratigraphy of the Great Basin and Rocky Mountains: Brigham Young University Geology Studies, v. 26, pt. 3, $190 \mathrm{p}$.

Sandberg, C. A., Grogan, D. R., and Clisham, T. J., 1979, Mississippian source rocks in Utah and Idaho: U.S. Geological Survey Professional Paper 1150, p. 28-29.

Sandberg, C. A., and Gutschick, R. C., 1977, Paleotectonic, biostratigraphic, and economic significance of Osagean to early Meramecian starved basin in Utah: U.S. Geological Survey Open-File Report 77-121, 16 p, 5 figs.

1979 , Guide to conodont biostratigraphy of Upper Devonian and Mississippian rocks along the Wasatch Front and Cordilleran Hingeline, Utah, in Sandberg, C. A., and Clark, D. L., eds., Conodont biostratigraphy of the Great Basin and Rocky Mountains: Brigham Young University Geology Studies, v. 26, pt. 3, p. 107-134, 16 figs:

$-1980 \mathrm{a}$, Sedimentation and biostratigraphy of Osagean and Meramecian starved-basin and foreslope, Western United States, in Fouch, T. D., and Magathan, E. R., eds., Paleozoic paleogeography of the west-central United States: Society of Economic Paleontologists and Mineralogists, Rocky Mountain Section, Rocky Mountain Paleogeography Symposium 1, p. 129-147. 
-1980b, Sedimentation, biostratigraphy, and source-rock potential of Deseret starved basin (Mississippian), Western United States [abs.]: American Association of Petroleum Geologists Bulletin, v. 64, no. 5, p. 779-780.

1983, Deep-water phosphorite in Early Carboniferous Deseret starved basin, Utah, U.S.A., in World phosphate resources: International Geological Correlation Program Project No. 156-Phosphorites, Working Group 2, International Phosphate Resource Data Base [in press].

Sandberg, C. A. Gutschick, R. C., Johnson, J. G., Poole, F. G., and Sando, W.J., 1982, Middle Devonian to Late Mississippian geologic history of the Overthrust belt region, western United States, in Geologic studies of The Cordilleran thrust belt: Rocky 'Mountain Association of Geologists, v. 2, p. 691-719.

Sandberg, C. A., and Poole, F. G., 1975, Petroleum source beds in Pilot Shale of eastern Great Basin-Talk for Oil and Gas Session I, Rocky Mountain Section Meeting, American Association of Petroleum Geologists, Albuquerque, New Mexico, June 2, 1975: U.S. Geological Survey Open-File Report 75-371, 13 p., 4 figs.

1977, Conodont biostratigraphy and depositional complexes of Upper Devonian cratonic-platform and continental-shelf rocks in the Western United States, in Murphy, M. A., Berry, W. B. N., and Sandberg, C. A., eds., Western North America; Devonian: California University, Riverside, Campus Museum Contribution 4, p. 144-182.
Sandberg, C. A., Poole, F: G., and Gutschick, R. C., 1980, Devonian and Mississippian stratigraphy and conodont zonation of Pilot and Chainman Shales, Confusion Range, Utah, in Fouch, T. D., and Magathan, E. R., eds., Paleozoic paleogeography of the west-central United States: Society of Economic Paleontologists and Mineralogists, Rocky Mountain Section, Rocky Mountain Paleogeography Symposium 1, p. 71-79.

Sharp, G. C., 1978, Upper Valley, in Oil and gas fields of the Four Corners area: Four Corners Geological Society, v. 2, p. 709-711.

Smith, R. M., and Brown, K. W., 1981, Utah mineral industry activity review and summary of oil and gas drilling and production, 1980: Utah Geological and Mineral Survey Circular $71,31 \mathrm{p}$.

Smith, K. T., and Prather, O.E., 1981, Lisbon field-lessons in exploration, in Rocky Mountain Association of Geologists Guidebook, 1981 Field Conference, Geology of the Paradox basin, p. 55-59.

Spencer, C. W., 1975, Petroleum geology of east-central Utah and suggested approaches to exploration, in Four Corners Geological Society guidebook, 8th Field Conference, Canyonlands Country, p. 263-275.

Sweet, W. C., Harris, A. G., Sandberg, C. A., and Wardlaw, B. R., 1981, Conodonts; guides to biostratigraphy and geothermometry in the western United States, in Montana Geological. Society Field Conference and Symposium Guidebook to Southwest Montana: p. 133-137. 